\title{
Effect of Selected Botanicals and their Commercial Products against Alternaria Blight of Cabbage (Alternaria brassicae)
}

\author{
S. Chethan Kumar*, Sunil Zacharia and Shashi Tiwari \\ Department of Plant Pathology, Sam Higginbottom University of Agriculture, Technology and \\ Sciences, Prayagraj, Uttar Pradesh, India - 211007 \\ *Corresponding author
}

\section{A B S T R A C T}

\begin{tabular}{l} 
Ke y w o r d s \\
$\begin{array}{l}\text { Alternaria } \\
\text { brassicae, Botanical } \\
\text { extracts, Botanical } \\
\text { fungicides, } \\
\text { Essential oil, } \\
\text { cabbage }\end{array}$ \\
$\begin{array}{l}\text { Article Info } \\
\text { Accepted: } \\
\text { 07 August } 2020 \\
\text { Available Online: } \\
\text { 10 September } 2020\end{array}$ \\
\hline
\end{tabular}

\section{Keywords}

Alternaria brassicae, Botanical fungicides, Essential oil

\section{Introduction}

Cabbage is one of the most popular and widely grown vegetable in the world. Botanical name is Brassica oleracea var capitata L. It belongs to family Cruciferae. Alternaria blight, disease caused by Alternaria brassicae and Alternaria brassicicola is the most devasting disease of cabbage. Alternaria brassicae and Alternaria brassicicola, they can survive saprophytically outside of the host and diseased crop debris (Yadav et al., 2014).

\begin{abstract}
An experiment was conducted to evaluate the effect of three botanical extracts, two botanical fungicides and one essential oil in vitro and in vivo against Alternaria brassicae causing Alternaria blight of cabbage. Among the treatments basil essential oil was found most effective in the inhibition of mycelial growth of Alternaria brassicae followed by Oenanthol (castor based botanical fungicide), bloom buddy (neem based botanical fungicide), neem leaf extract, basil leaf extract and castor leaf extract at all the three different concentrations tested in laboratory condition as compared to untreated ntrol.The botanical extracts and their commercial products were tested under field dition during rabi 2019-2020 for their efficacy against the disease. Among the treatments minimum percent disease intensity was recorded in Bloom buddy (neem based botanical fungicide) @ $0.5 \%(23.35 \%)$ followed by Oenanthol (castor based botanical fungicide)@0.1\% (25.15\%), basil essential oil @ 2\% (26.20\%), neem leaf extract @ 25\% (28.31\%), basil leaf extract @ 5\% (30.12\%) and castor leaf extract @ 30\% (31.50\%) as compared to untreated control $(34.43 \%)$.
\end{abstract}

The genus is characterized by the formation of polymorphous conidia either singly or in short or longer chains and provided with cross, longitudinal as well as oblique septa and having longer or short beaks (Nayyar et al., 2014).

The disease occurs in all parts of the world where cabbage is grown. The disease caused by this fungus is characterized by yellowbrown spots with target-like concentric rings which appear on leaves, as well as dark brown sunken spots on heads. The causal organism 
is both air borne and soil inhabiting. It affects every part of infected plant.

A temperature range of 25 to $30^{\circ} \mathrm{C}$ and 15 to $35^{\circ} \mathrm{C}$ was found optimum for mycelial growth and sporulation of $A$. brassicae, respectively. Mycelial growth was most favoured by $100 \%$ relative humidity with a gradual reduction in growth and sporulation till $70 \% \mathrm{RH}$ and a decrease in growth and sporulation at 60 and 50\% RH (Meena et al., 2012).

Regular use of chemical fungicide is hazardous for the soil and for humans as well. Thus, utilization of botanical extracts, botanical fungicides and essential oils in disease management is considered as ecofriendly, without any environmental pollution. Botanical extracts have been used in disease management for long time as foliar spray is rarely followed approach and needs screening in different crops and under different environmental conditions. The present study was carried out to explore the efficiency of some botanical extracts and their commercial products, under in vitro and in field condition at Sam Higginbottom University of Agriculture, Technology and Sciences, Prayagraj, (U. P), India.

\section{Materials and Methods}

\section{In vitro Experiment}

botanical extracts of castor $(20 \%, 30 \%$ and $40 \%)$, basil (5\%, 10\% and 15\%) and neem $(15 \%, 25 \%$ and $35 \%)$ and botanical fungicides namely, oenanthol (castor based botanical fungicide $0.1 \%, 0.2 \%$ and $0.3 \%$ ), bloom buddy (neem based botanical fungicide $0.3 \%, 0.5 \%$ and $0.7 \%$ ) and basil essential oil $(1.0 \%, 2.0 \%$ and $3.0 \%)$ were tested for their efficacy against Alternaria brassicae under in vitro by using poison food technique on Potato dextrose agar medium.
The selected fresh leaves of healthy plants were collected and washed thoroughly with clean water and dried to drain the water. About $10 \mathrm{~g}$ of plant leaves were grounded using pestle and mortar by adding same proportion $(10 \mathrm{ml})$ of sterilised distilled water in weight by volume method. The botanical extract thus obtained by grounding was filtered through muslin cloth and the extract was diluted by adding sterilised distilled water to get required concentration. Calculated concentration of botanical extracts, botanical fungicides and essential oil were thoroughly mixed in the medium. Twenty $\mathrm{ml}$ of amended medium was poured in $90 \mathrm{~mm}$ sterilized Petri-plates and allowed to solidify. Mycelial disc of $5 \mathrm{~mm}$ from seven day old actively growing culture was inoculated at the centre of the plate and then incubated at $28 \pm$ $2^{\circ} \mathrm{C}$ for 4 days.

Control was maintained without any treatment. Three replications were maintained for each treatment with three different concentrations and data was recorded. Control was maintained where in only test fungus was grown. The plates were incubated at $28 \pm 2{ }^{\circ} \mathrm{C}$ for four days. The experiment was conducted in completely randomized block design (CRD) with three replications in each treatment. Percent inhibition was calculated by using the formula given by Vincent (1947).

Per cent inhibition of colony $=-$ C-T
Where
$\mathrm{C}=$ Colony diameter in control
$\mathrm{T}=$ Colony diameter in treatment

\section{In vivo experiment}

Field experiment was laid-out in Randomized block design with three replications. Two sprays were given at an interval of 15 days. Treatments were imposed after appearance of 
the first disease symptoms. Observations on percent disease intensity was recorded by using 1-9 disease rating scale at 15 days interval and yield data were obtained after the harvest based on physiological maturity.

\section{Results and Discussion}

Per cent inhibition of mycelial growth and mean colony diameter of Alternaria brassicae as affected by treatments at different concentrations

The data presented in table 1 for evaluation of per cent inhibition of mycelial growth over control as affected by treatments against Alternaria brassicae reveals that basil essential oil was found most effective followed by oenanthol (castor based botanical fungicide), bloom buddy (neem based botanical fungicide), neem leaf extract, basil leaf extract and castor leaf extract at all the three different concentrations tested in laboratory condition as compared to untreated control.

Basil essential oil recorded maximum per cent inhibition in the mycelial growth of the pathogen. Similar findings have been reported by Mona et al., (2016), Momoh et al., (2012), Chandhan et al., (2013) and Sasode et al., (2012). The probable reason for such findings may be due the fungitoxic properties exhibited by essential oil (Fig. 1-3).

Field evaluation of selected botanicals and their commercial products against the Alternaria blight of cabbage caused by the Alternaria brassicae (Table 2)

A field study was carried out to assess the efficacy of botanical extracts, botanical fungicides and essential oil against Alternaria blight (Alternaria brassicae) of cabbage with two sprays taken up at 45 DAT and 60 DAT during rabi 2019-2020. Two sprays were given at 45 DAT and 60 DAT. Results revealed that bloom buddy (neem based botanical fungicide) [23.35\%] was found most effective in minimizing the per cent disease incidence and getting higher yields. Followed by oenanthol (castor based botanical fungicide) [25.15\%], basil essential oil (26.20\%), neem leaf extract (28.31\%), basil leaf extract $(30.12 \%)$ and castor leaf extract $(31.50 \%)$ as compared with untreated control $(34.43 \%)$. Thus, the study indicated that suitable integration of more efficient ecofriendly treatments like botanical extracts and their commercial products with minimum usage of chemical fungicides may provide a better and effective management of the disease

In the field condition, bloom buddy (neem based botanical fungicide) was found most effective amongst all the treatments for the management of Alternaria blight caused Alternaria brassicae. Minimum per cent disease intensity $(23.35 \%)$ was recorded with the same. Similar findings regarding the antifungal property of neem have been reported by Mohiddin et al., (2008), Ranaware et al., (2010) and Utkarsh et al., (2018).

Basil essential oil which recorded maximum inhibition of the mycelial growth of the pathogen under in vitro conditions was not able to manage disease in the field conditions as efficiently as botanical fungicides when used as foliar spray. The probable reason for such findings may be due to fungal growth inhibition by neem-based botanical fungicide which works in various ways, involves prevention of hyphal growth and sporulation. 
Table.1 Per cent inhibition of mycelial growth and mean colony diameter of Alternaria brassicae as affected by treatments at different concentrations

\begin{tabular}{|c|c|c|c|c|c|c|c|c|}
\hline \multirow{3}{*}{ Treatments $(\mathrm{T})$} & \multicolumn{4}{|c|}{ Mean Colony diameter } & \multicolumn{4}{|c|}{ Percent inhibition } \\
\hline & \multicolumn{4}{|c|}{ Concentrations(C) } & \multicolumn{4}{|c|}{ Concentrations(C) } \\
\hline & $\mathrm{C}_{1}$ & $\mathrm{C}_{2}$ & $\mathrm{C}_{3}$ & Mean (T) & $\mathrm{C}_{1}$ & $\mathrm{C}_{2}$ & $\mathrm{C}_{3}$ & Mean (T) \\
\hline $\mathbf{T}_{\mathbf{0}}$ & 90.00 & 90.00 & 90.00 & 90.00 & 0.00 & 0.00 & 0.00 & 0.00 \\
\hline $\mathbf{T}_{1}$ & 62.33 & 43.33 & 40.33 & 48.67 & 58.47 & 51.83 & 30.70 & 47.00 \\
\hline $\mathbf{T}_{2}$ & 22.33 & 0.00 & 0.00 & 7.44 & 100.00 & 100.00 & 74.90 & 91.63 \\
\hline $\mathbf{T}_{3}$ & 55.00 & 43.00 & 37.00 & 45.00 & 58.20 & 52.20 & 38.86 & 49.75 \\
\hline $\mathbf{T}_{4}$ & 0.00 & 0.00 & 0.00 & 0.00 & 100.00 & 100.00 & 100.00 & 100.00 \\
\hline $\mathbf{T}_{5}$ & 52.33 & 41.67 & 39.33 & 44.44 & 56.27 & 53.67 & 41.80 & 50.58 \\
\hline $\mathbf{T}_{6}$ & 24.67 & 23.33 & 20.33 & 22.78 & 76.67 & 74.33 & 72.33 & 74.44 \\
\hline \multirow[t]{2}{*}{ Mean (C) } & 43.81 & 34.48 & 32.43 & & 64.23 & 61.72 & 51.23 & \\
\hline & F-test & $\begin{array}{c}\text { S. Em. } \\
( \pm)\end{array}$ & $\begin{array}{c}\text { C.D. at } \\
5 \%\end{array}$ & & F-test & $\begin{array}{c}\text { S. Em. } \\
( \pm)\end{array}$ & $\begin{array}{c}\text { C.D. at } \\
5 \%\end{array}$ & \\
\hline Treatments & $\mathbf{S}$ & 1.025 & 2.093 & & $\mathbf{S}$ & 1.404 & 2.866 & \\
\hline Concentration & $\mathbf{S}$ & 0.725 & 1.480 & & $\mathbf{S}$ & 0.993 & 2.027 & \\
\hline Int. (T x C) & $\mathbf{S}$ & 1.776 & 3.626 & & $\mathbf{S}$ & 2.431 & 4.965 & \\
\hline
\end{tabular}

Where, $\mathrm{C}_{1}$ - low concentration; $\mathrm{C}_{2}$ - Medium concentration; $\mathrm{C}_{3}$ - High concentration

Table.2 Percent disease intensity at 30DAT, 45 DAT and 60 DAT as affected by treatments

\begin{tabular}{|c|c|c|c|c|c|c|}
\hline \multirow[b]{2}{*}{ Sl no } & \multirow[b]{2}{*}{ Treatments } & \multirow[t]{2}{*}{ Dosage } & \multicolumn{4}{|c|}{ PDI } \\
\hline & & & $\begin{array}{l}30 \text { DAT Before } \\
\text { spray }\end{array}$ & $\begin{array}{l}45 \text { DAT after } \\
1^{\text {st }} \text { spray }\end{array}$ & $\begin{array}{l}60 \text { DAT after } \\
2^{\text {nd }} \text { spray }\end{array}$ & Mean \\
\hline $\mathbf{T}_{0}$ & Control(untreated) & - & 23.33 & 35.07 & 45.94 & 34.43 \\
\hline $\mathbf{T}_{1}$ & Castor leaf extract & $30 \%$ & 22.29 & 32.16 & 39.02 & 31.50 \\
\hline $\mathbf{T}_{2}$ & $\begin{array}{l}\text { Oenanthol (castor based botanical } \\
\text { fungicide) }\end{array}$ & $0.1 \%$ & 20.05 & 26.06 & 29.35 & 25.15 \\
\hline $\mathbf{T}_{3}$ & Basil leaf extract & $5 \%$ & 22.21 & 31.67 & 36.42 & 30.1 \\
\hline $\mathbf{T}_{4}$ & Basil essential oil & $2 \%$ & 19.71 & 27.23 & 31.68 & 26.20 \\
\hline $\mathbf{T}_{5}$ & Neem leaf extract & $25 \%$ & 22.64 & 29.36 & 32.95 & 28.31 \\
\hline $\mathbf{T}_{6}$ & $\begin{array}{l}\text { Bloom buddy (neem based botanical } \\
\text { fungicide) }\end{array}$ & $0.5 \%$ & 20.48 & 23.28 & 26.29 & 23.35 \\
\hline \multicolumn{3}{|c|}{ SEd \pm C } & 0.63 & 0.61 & 1.57 & \\
\hline \multicolumn{3}{|c|}{ CD@5\% } & 1.95 & 1.88 & 4.84 & \\
\hline \multicolumn{3}{|c|}{$\mathrm{CV}(\%)$} & 5.1 & 3.6 & 7.9 & \\
\hline
\end{tabular}




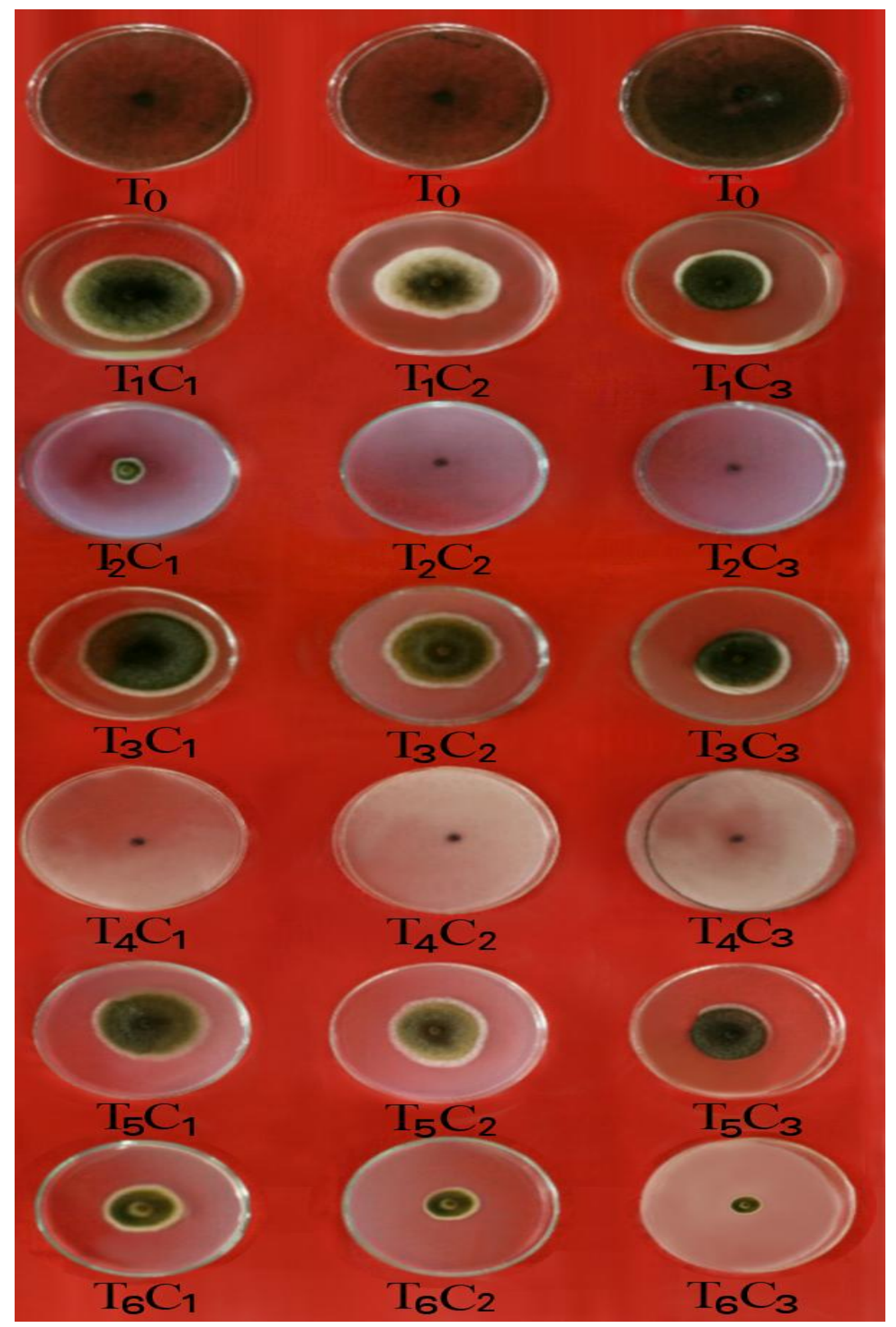

Plate 1. Per cent inhibition of mycelial growth and mean colony diameter of Alternaria brassicae as affected by treatments at different concentrations. 
Fig.1 Mean colony diameter of Alternaria brassicae as affected by treatments at different concentrations

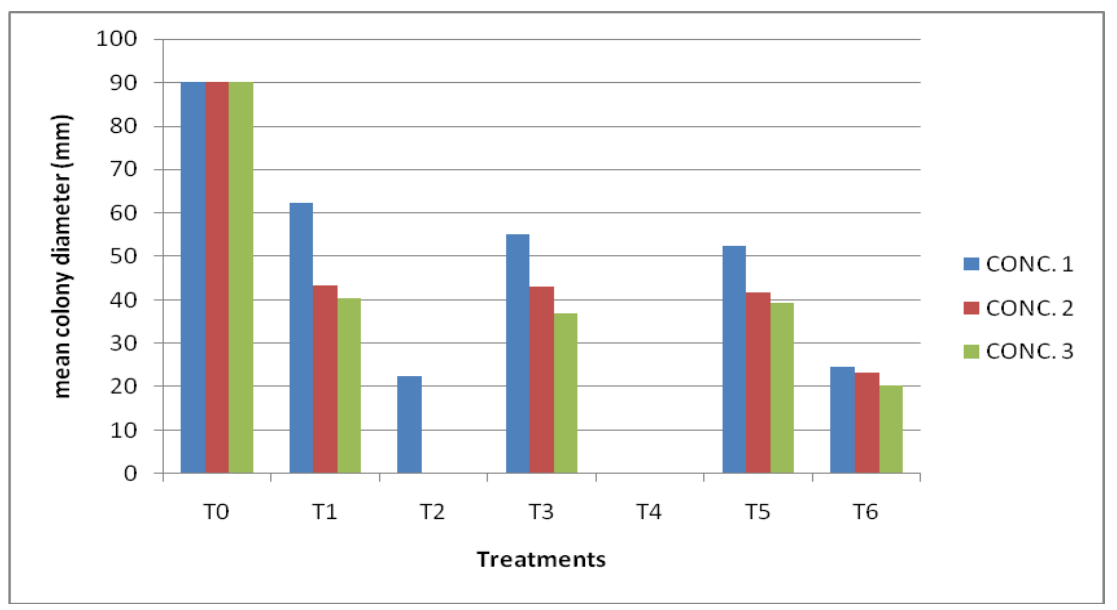

Fig.2 Percent inhibition of mycelial growth of Alternaria brassicae as affected by treatments at different concentrations

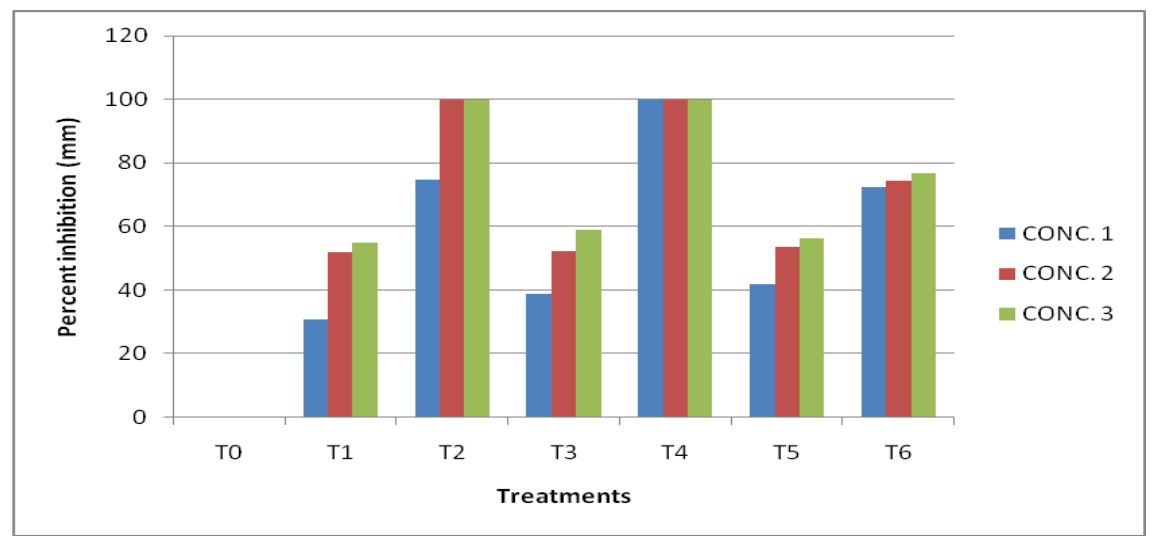

Fig.3 Per cent disease intensity at 30 DAT, 45 DAT and 60 DAT as affected by treatments

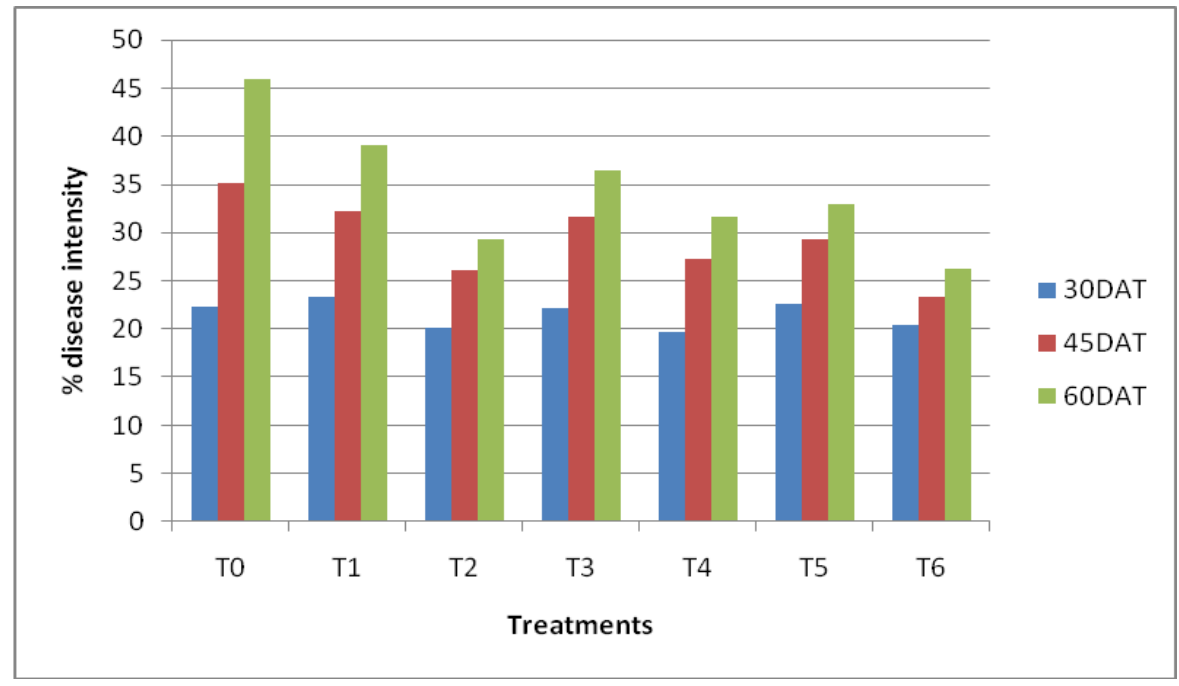


In concluding the present study, it was found that basil essential oil was most effective against Alternaria brassicae, causing Alternaria blight disease of cabbage under invitro condition. The treatment recorded maximum per cent inhibition of mycelia growth of the pathogen. Under field condition, bloom buddy (neem based botanical fungicide) @0.5\% was found most effective against $A$. brassicae, which recorded minimum disease intensity (23.35\%). Therefore, it may be recommended for the better management of Alternaria blight disease of cabbage. The results of the present experiment are limited to one crop season (Nov. 2019- Jan. 2020) under Prayagraj agroclimatic conditions, as such to validate the present findings more such trials should be taken up in future.

\section{Acknowledgement}

The Authors are thankful to Department of Plant pathology, SHUATS, Naini agricultural institute, Prayagraj, for taking their keep interest and encouragement to carry out the research work.

\section{References}

Bayaso, I., Nahunnaro, H. and Gwary, D.M. (2013). Effects of aqueous extract of Ricinus communis on radial growth of Alternaria solani. African Journal of Agricultural Research. 8(37): 4541-4545.

Chandan Kumar Singh, Shafaat Ahmad and Abhilasha A. Lal. (2013). Comparative study of certain plant extracts and Trichoderma viride in the management of Alternaria leaf spot of Cabbage. The Allahabad farmer vol. LXX, January -2015
NO.2

Meena, P. D., Rani, A., Meena, R., Sharma, P., Guptha, R. and Chowdappa, P. (2012).Aggressiveness, diversity and distribution Alternaria brassicae isolates infecting oil seed brassicae in India. African Journal of Microbiology Research. 6(24): 5249-5258.

Mohiddin, F. A., Khan, M. R. and Khan, M. M. (2008). Comparative efficacy of various spray schedules of some plant extracts for the management of Alternaria blight of Indian mustard. Trends in Biosciences. 1 (1/2): 50-51.

Momoh, A.O., Oladunmoye, M.K. and Adebolu, T.T. (2012). Evaluation of the Antimicrobial and Phytochemical Properties of oil from Castor Seeds. Bulletin of Environment, Pharmacology and Life Sciences. 1(10): 21-27

Nayyar, B. G., Akhund, S. and Akram, A. (2014). Management of Alternaria and its mycotoxins in crops. Scholarly Journal of Agricultural Science. 4(7):432-437.

Ranaware, A., Singh, V. and Nimbkar, N. (2010). In vitro antifungal study of the efficacy of some plant extracts for inhibition of Alternaria carthami fungus. Indian Journal of Natural Products and Resources. 1(3):384-386.

Utkarsh Singh Rathore, Singh, S.K., Sandeep Kumar and Solani Rishi. (2018). Application of botanicals for effective management of Alternaria blight of Pigeon Pea. Journal of Pharmacognosy and Phytochemistry. SP2: 328-330

Yadav, C. L., Kumar, N. and Kumar, R. (2014). Effect of Seed Treatments with Fungicides Bio-agents and Botanicals against Alternaria leaf spot in cabbage (Brassica oleraceae var. capitata L.). Trends in Biosciences, 7(23):3823-3827.

\section{How to cite this article:}

Chethan Kumar, S., Sunil Zacharia and Shashi Tiwari. 2020. Effect of Selected Botanicals and their Commercial Products against Alternaria Blight of Cabbage (Alternaria brassicae). Int.J.Curr.Microbiol.App.Sci. 9(09): 571-577. doi: https://doi.org/10.20546/ijcmas.2020.909.072 